\title{
INFLUÊNCIAS DA COVID-19 NA PROPAGAÇÃO DE MEMES EM PÁGINAS FUTEBOLÍSTICAS DO INSTAGRAM
}

Recebido em: 05/08/2020

Aprovado em: 24/08/2020

Licença: @) $(1) \Theta$

Wesley Marques da Silva ${ }^{1}$

Universidade do Estado de Minas Gerais (UEMG)

Ituiutaba - MG - Brasil

Ari Lazzarotti Filho ${ }^{2}$

Universidade Federal de Goiás (UFG)

Goiânia - GO - Brasil

RESUMO: Objetiva-se com esta pesquisa compreender como a pandemia de COVID19 influenciou na vivência de atividades do lazer por meio da propagação de memes, nos seus temas e tipos, em páginas futebolísticas no Instagram. Trata-se de uma pesquisa de campo que teve como técnica de coleta de dados o diário de bordo, sendo delimitado como tempo de coleta os trinta dias anteriores e posteriores à nota de 16 de março de 2020 publicada pela Confederação Brasileira de Futebol, que suspendeu os campeonatos de futebol por tempo indeterminado, como medida de combate à COVID-19 no Brasil. Conclui-se que a pandemia de COVID-19 influenciou no aumento de veiculação de memes futebolísticos, redirecionando seus temas para outras manifestações da cultura brasileira e também alterou a propagação por seus tipos, com ênfase para os memes verbo visual e verbo audiovisual.

PALAVRAS-CHAVE: Memes Futebolísticos. COVID-19. Atividades de Lazer.

\section{INFLUENCES OF COVID-19 ON THE PROPAGATION OF MEMES IN INSTAGRAM'S FOOTBALLISTIC PAGES}

ABSTRACT: The objective of this research is to understand how the pandemic of COVID-19 influenced the experience of leisure activities through the spread of memes, in their themes and types, on football pages on Instagram. This is a field research that used the logbook as a data collection technique, with the collection time limited to the thirty days before and after the March 16, 2020 note from the Brazilian Football Confederation, which suspended the football championships indefinitely, as a measure to combat COVID-19 in Brazil. It is concluded that the COVID-19 pandemic influenced the increase in the spread of soccer memes, redirecting their themes to other manifestations

\footnotetext{
${ }^{1}$ Professor no curso de Educação Física da Universidade do Estado de Minas Gerais (UEMG). Doutorando em Educação Física pela Universidade de Brasília - UnB. Vinculado aos grupos de pesquisa, GEPELC e LabDim.

${ }^{2}$ Professor do Programa de Pós-graduação em Educação da Universidade Federal de Goiás-UFG de do Programa de Pós-graduação em Educação Física da Universidade de Brasília. Membro do Grupo de Estudo e Pesquisa em Esporte, Lazer e Comunicação-GEPELC.
} 
of Brazilian culture and also changed the propagation by their types, with emphasis on the visual verb and audiovisual verb memes.

KEYWORDS: Football Memes. COVID-19. Leisure Activities.

\section{Introdução}

A pandemia decorrente da doença COVID-19, causada pelo coronavírus SARSCoV-2, reorganizou as mais diversas searas da vida cotidiana e impactou na vivência das atividades do lazer dos brasileiros. A quarentena, medida que objetivou o distanciamento social na tentativa de diminuição da propagação do vírus, modificou uma parte considerável das obrigações sociais, religiosas, familiares, de trabalho e lazer.

Descoberta em 31 de dezembro de 2019, em Wuhan, na China, a doença possui como sintomas mais comuns a tosse, febre, coriza, dor de garganta e dificuldade de respiração. Trata-se de uma patologia que se manifesta desde um simples resfriado até uma pneumonia severa, cuja transmissão ocorre entre uma pessoa infectada pelo vírus para outra via gotículas de saliva, tosse, espirro, secreções, aperto de mãos ou contato com superfícies contaminadas e contactadas às vias orais, nasais ou oculares (MACEDO; ORNELLAS; BOMFIM, 2020).

O Ministério da Saúde do Brasil, tendo como base a Organização Mundial de Saúde, tem orientado um conjunto de medidas de proteção contra a doença que incluem desde a higienização das mãos e aparelhos de uso corrente, o não compartilhamento de objetos pessoais, bem como evitar tocar olhos, nariz e boca, e, ao tossir ou espirrar, cobrir o nariz ou boca com o braço, além de manter distância de no mínimo 2 metros entre pessoas, e evitar contatos físicos e aglomerações, além do uso de máscaras. Para o caso em que estejam presentes os sintomas da doença, o doente deve manter-se em isolamento ou então, caso apresente falta de ar, procurar os serviços de saúde (BRASIL, 2020).

licere, Belo Horizonte, v.23, n.3, set/2020. 
Até o instante de finalização da escrita deste artigo, o Brasil registrava, oficialmente, 2.483.191 casos da COVID-19. Recuperados, desse total, eram 1.721.560, e mortos, 88.539. Painel Coronavírus. Ministério da Saúde, 2020. Disponível em: https://covid.saude.gov.br// Acessado em: 29/07/2020. Não obstante, não havia cura à doença, sendo adotado, em diversos países e aqui no Brasil, o sistema de distanciamento social como forma de conter a proliferação.

O distanciamento social obrigou a tomada de atitudes em vários setores da sociedade brasileira. Com efeito, a Confederação Brasileira de Futebol (CBF), a partir do dia 16 de março, suspendera, por tempo indeterminado, as competições nacionais até então em andamento, a saber: Copa do Brasil, Campeonatos Brasileiros Femininos A1 e A2, Campeonato Brasileiro Sub-17 e Copa do Brasil Sub-20 (CBF, 2020). Essa suspensão foi seguida pelas federações estaduais.

Com as competições canceladas, a mídia encontrou outras maneiras de manter o futebol, nomeadamente por meio de reprises de jogos, entrevistas com jogadores, campeonatos eletrônicos com jogadores profissionais, entre outros; e o espaço virtual, em específico, o Instagram se fez presente também como uma forma de prática e contemplação de lazer deste fenômeno.

A vivência de atividades do lazer nos espaços virtuais está relacionada aos aspectos do tempo e atitude. Tais espaços viabilizam a interação do sujeito sem a necessidade do deslocamento físico, criando sua rede de comunicação própria em razão de seus interesses. Ou ainda, o espaço virtual é um potencializador interativo dos conteúdos virais, e os memes são produtos virais que se perpetuam por meio de seus replicadores, as pessoas.

A partir da quebra de rotina, decorrente do distanciamento social, neste artigo busca-se compreender como a pandemia de COVID-19 influenciou na vivência de 
atividades do lazer relativamente à propagação de memes, nos seus temas e tipos, em páginas futebolísticas no Instagram.

É importante salientar que a vivência das atividades do lazer, nessas páginas, derivada da produção e propagação de memes sem o uso de publicização e monetização, é possível graças aos criadores de conteúdo (CDC's), responsáveis por alimentar esses espaços virtuais com memes. Por sua vez, tal fato implica no consumo e na apropriação das mídias, seja na elaboração primária ou na replicação.

Portanto, a propagação de memes por CDC's gera significados de lazer aos mesmos, os quais podem, por meio da produção ou da replicação, ressignificar e difundir suas vivências de lazer notadamente aquelas relacionadas ao futebol para consumo dos seus seguidores. Cabe ressaltar que o período de coleta de dados correspondeu aos trinta dias anteriores e posteriores à nota da CBF postada em três páginas futebolísticas de Instagram.

\section{Memes, Futebol e Lazer no Espaço Virtual}

O termo meme é geralmente usado para se referir a uma composição de imagens/textos e áudio/vídeo, de natureza imitativa e digital transmitida pela rede, capaz de evoluir à medida que viaja virtualmente. No entendimento de Fontanella (2009, p.8), os memes são "ideias, brincadeiras, jogos, piadas ou comportamentos que se espalham através de sua replicação de forma viral, e caracterizada pela repetição de um modelo formal básico a partir da qual pessoas podem produzir diferentes versões do mesmo meme".

As primeiras discussões sobre memes foram realizadas por Dawkins (2001), que citou a imitação em seu sentido amplo como a responsável pela replicação dos memes baseada em três elementos fundamentais, nomeadamente a mutação, seleção e 
hereditariedade. A mutação seria as variações que ocorrem na base inicial no decorrer das postagens, gerando mudanças nas replicagens; a seleção está relacionada a propagação e sobrevivência, entre sentimentos de ostracismo e a proliferação de ideias; já a hereditariedade se direciona à dinâmica entre pouca variação e recombinação do meme original.

Segundo o mesmo autor, quanto a sobrevivência, o meme possui características de longevidade, fecundidade e fidelidade. A longevidade é a permanência do meme no espaço virtual; a fecundidade é medida pelo processo de gerar cópias, e a fidelidade em manter o mais próximo possível a ideia original. Cabe salientar que uma das características atuais, com o uso dos smartphones, é a facilidade quanto a utilização das tecnologias da informação e comunicação, e que os memes podem produzir sentidos e ressignificações. Recuero (2009, p.124) cita:

A propagação dos memes é cíclica e nem sempre implica a reprodução fiel da ideia original. Ao contrário, as mudanças e transformações são frequentes e comparadas, em sua abordagem, às mutações genéticas: essenciais para a sobrevivência do meme. Assim, as diferenças através das quais as pessoas repetem as ideias são, por definição, parte do meme.

A autora acrescenta uma quarta característica, o alcance, que pode ser compreendido pela difusão de publicações e possível atingimento do número de nós na rede por uma mesma informação (meme), sendo associado ao valor percebido de sua difusão.

Ainda segundo a mesma autora, os memes podem ser classificados a partir da fidelidade, longevidade, fecundidade e alcance. Quanto à fidelidade a) replicadores característico por pouca variação a cópia original, possuem caráter informativo, no sentido de difusão de ideias; b) metamórficos - compreendem na transformação, recombinação e transformação do meme originário; c) miméticos - são memes que mantém a estrutura inicial adaptando-se ao espaço que serão publicados. 
Quanto à longevidade: d) persistentes - são memes que se mantêm sendo replicados por um grande espaço de tempo, podendo desaparecer e voltar posteriormente; e) voláteis - possuem curto período de replicagem, ou perdem a essência inicial e caem no ostracismo.

Quanto à fecundidade: f) epidêmicos - possuem grande fecundidade, atingem a amplitude em várias redes; g) fecundos - memes não epidêmicos, ao alcance de grupos menores. Por último quanto ao alcance: h) globais - memes de alcance de nós distantes entre si; i) locais - memes propagados por atores próximos que se interagem com maior frequência, podem se tornar globais quando extrapolam a noção de espaço do grupo.

Para sua produção, os memes seguem a lógica atinente à replicação e alteração do que é imitável em sua raiz, ou produção primária. Constituem a base produtora de memes primários o app (aplicativo) ou sites (endereços eletrônicos), que servem de referência e facilitam essas práticas.

A criação de memes nessas plataformas é gratuita, de fácil acesso e manuseio, iniciando-se com a escolha de um template (estrutura pré-definida pelo programa que facilita a construção de algo a partir de disponibilidade a priori, geralmente identificada por imagens, ou imagens com textos).

Escolhido o template nos arquivos já presentes nos app ou sites de criação, o próximo passo é customizá-lo, ou seja, criar identidade, escolher fonte e escrever texto ou produzir vídeo, quando necessário. Existe também a possibilidade da inserção de um template por upload (envio de arquivo de uma base de dados, seja pelo smartphone ou computador), a partir de um template em branco, o processo de customização é o mesmo.

Uma vez construído o meme, o próximo processo será o download (baixar o arquivo), sendo possível em formato de JPEG, PNG ou PDF, que posteriormente será veiculado e consumido pela população-alvo de quem o produziu. O processo de 
compartilhamento é simples, e inclui a escolha de várias redes sociais nas plataformas presentes nesses sites e app, para envio do conteúdo produzido, no caso específico do artigo, o Instagram.

Os memes podem ser tanto os produtos culturais acumulados, como aqueles gerados ou aperfeiçoados em direção à propagação, no transcorrer das vivências e das relações humanas dadas, que se efetivam no campo da coletividade e ganham, de certa forma, contornos estáveis, visando claramente uma assimilação, retenção, expressão, mas, por ora, também dados, via imitação como propõem ser, ou seja, o que é cultural é replicado por práticas imersas em linguagem.

São configurados como produções humanamente efetivadas e replicadas, regularizadas e relativamente estabilizadas no conjunto das práticas sociointeracionais, que são sensivelmente dependentes das combinações de natureza histórica, cultural, social e cognitiva. Ademais, podem ser classificados por seus tipos, os quais segundo Doncel (2016), variam em: a) verbo visual, que combinam uma fotografia, imagem ou desenho, no qual um texto é inserido (ver Figura1); b) visual, sua significação é percebida por meio da imagem em si (ver Figura 2); c) textual, o significado do meme é percebido pela leitura de escritas (ver Figura 3).

Acrescentemos a essa classificação os memes verbo audiovisual que combinam imagens, áudios e textos, possuindo características temáticas, identitárias e direcionadas, que os difere dos vídeos virais, por ser passíveis de modificação e possuírem um públicoalvo específico (ver Figura 4).

licere, Belo Horizonte, v.23, n.3, set/2020. 
Figura 1: Meme verbo-visual.

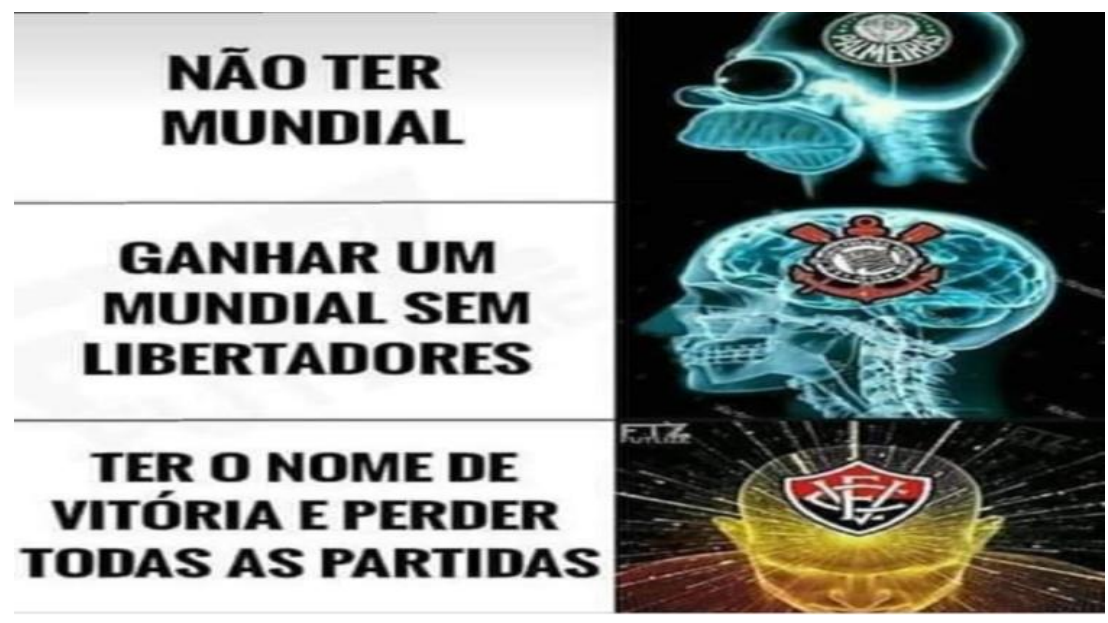

Disponível em: https://www.instagram.com/p/B-4yAVtBWGT/?utm_source=ig_web_button_share_sheet. Acesso em: 09 abr. 2020

Figura 2: Meme visual.

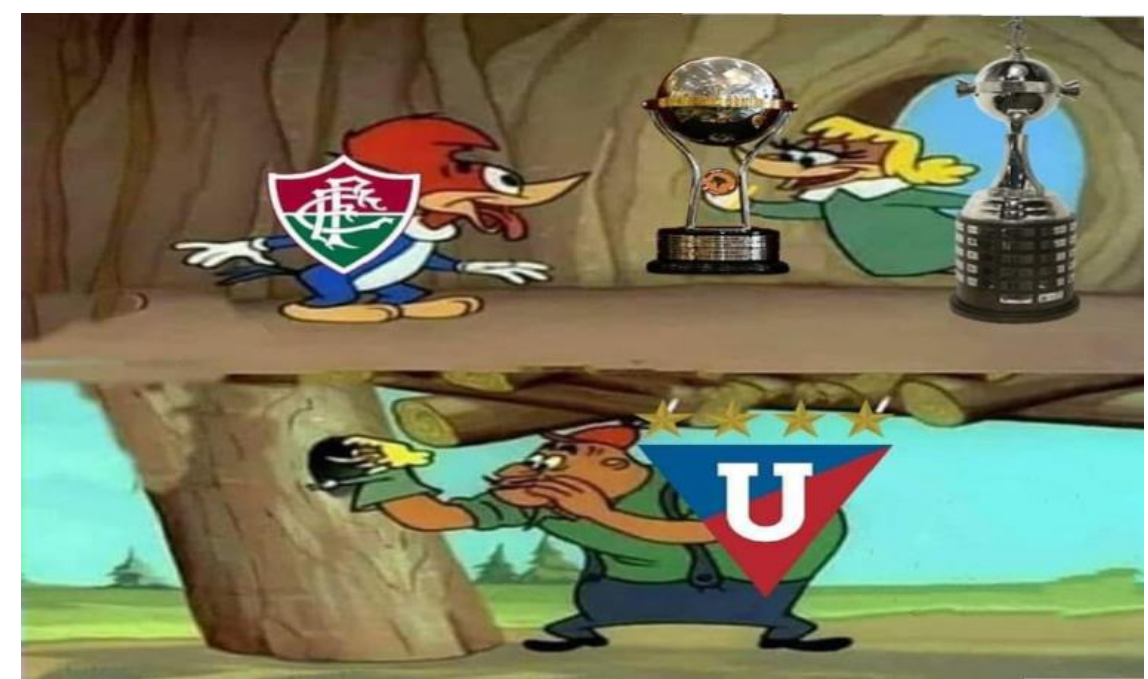

Disponível em: http://www.instagram.com/p/B-xA4B9hMVO/?utm_source=ig_web_button_share_sheet. Acesso em: 12 abr. 2020 
Figura 3: Meme textual.

\section{Se você tá achando ruim ficar de quarentena em casa, lembre-se que 0 Cruzeiro ficará por mais tempo na segunda divisão.}

Disponível em: www.instagram.com/opiortimeeoseu/ Acesso em: 22 mar. 2020

Figura 4: Meme verbo audiovisual.

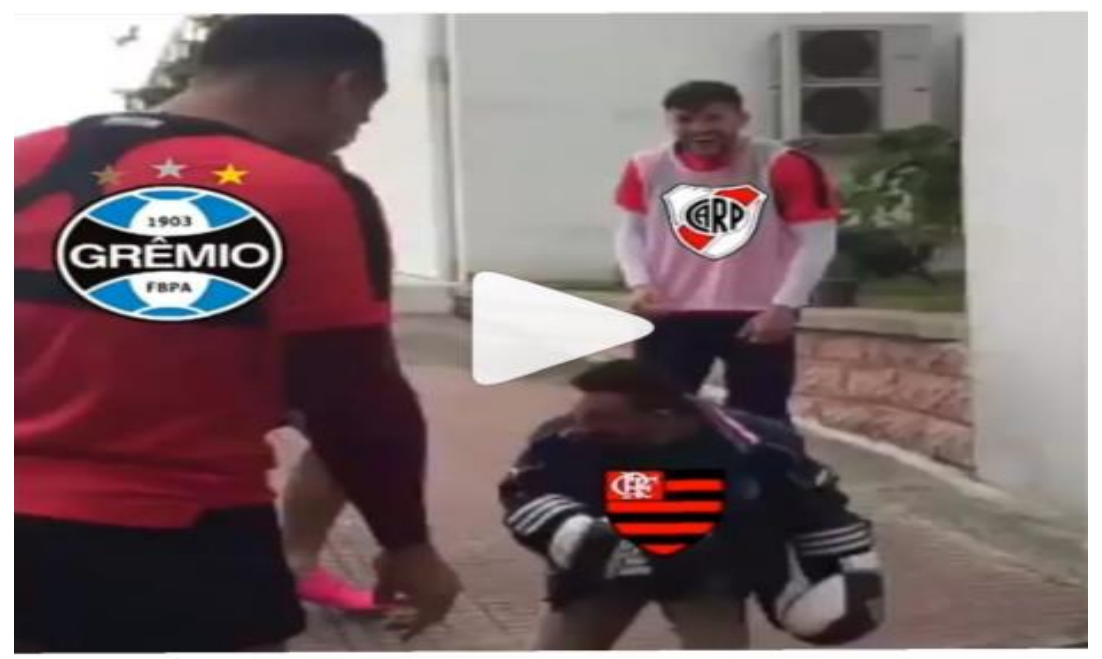

Disponível em: www.instagram.com/p/B1wp24-Fd6d/?utm_source=ig_web_options_share_sheet Acesso em: 13 abr. 2020

Os memes futebolísticos propagados em plataformas digitais podem prover significados de entretenimento antes possíveis apenas nas interações relacionadas ao futebol em bares, ruas, praças, estádios e residências. A relação do brasileiro com o futebol supera largamente as estreitas linhas do campo de jogo, sendo capaz de gerar uma monocultura percebida pelo espaço ocupado na vida dos indivíduos e a atribuição de um 
conjunto de significados, sendo os mesmos de diferentes lugares, estratos sociais, gêneros ou idades. Segundo Lages e Silva (2012, p.10):

O futebol está presente no cotidiano dos brasileiros, até daqueles que não gostam ou não se relacionam muito intimamente com esse. Tal esporte é considerado um fenômeno social-cultural na medida em que possibilita diferentes manifestações que são ressignificadas em diferentes contextos ao longo do tempo atuando na relação entre os indivíduos e a sociedade.

Para se entender este fenômeno, é preciso discuti-lo por meio de suas manifestações culturais, políticas e sociais. É uma paixão presente em quase todas as pessoas com representatividade do nosso jeito de ser e, portanto, é caminho de entendimento da própria nação por meio de identidades e identificações. Segundo Murad (2012, p. 18):

Identidade tem a ver com o "ser", com as manifestações culturais mais permanentes, que ajudam a entender e a definir um lugar e sua gente. Identificação tem a ver com o "estar", com as manifestações culturais mais imediatas, passageiras, e que às vezes tentam até mesmo esconder as identidades.

O mesmo autor entende o futebol como a modalidade esportiva de maior representatividade e popularidade mundial, e ainda que não seja tratado como tal, existem esforços de nações para que não se margeiem ao mundo do futebol, pois este representaria um considerável elo econômico, político e diplomático entre países.

Entre exemplos de popularização do futebol é citada a passagem do jogador Edson Arantes do Nascimento (Rei Pelé), pela equipe do Cosme dos EUA, e também do jogador Arthur Antunes Coimbra (Zico), pela equipe do Kashima Antlers do Japão, como tentativa de popularizar o esporte nesses respectivos países. Junto a esses exemplos, podese citar o caso recente da China, onde desembarcou jogadores e técnicos de renome internacional como forma de alavancar a liga do país e difundir a mesma.

Ainda segundo o autor essa popularização mundial se dá pelo fato de o futebol ser praticado em qualquer espaço, por ser imprevisível, possuir custo acessível de equipamentos, ser democrático e estável quanto a regras, além de possuir a maior 
associação de países federados a um órgão, no caso a FIFA, e produzir o maior telespetáculo esportivo, em termos de audiência e retorno financeiro, a Copa do Mundo, (MURAD, 2012).

O capital simbólico que marca o futebol permite dialogar nos extremos das dimensões positivas e negativas da identidade social do brasileiro, que pode ser percebida pelas manifestações que circundam eventos clubistas, selecionáveis ou como forma de expressão. A significação circundante de um clássico e ou de uma copa do mundo, os processos de sociabilidade e experimentação de emoções parecem alterar as regras cotidianas impressas.

Outros esportes no Brasil conseguem notoriedade de discussão quando estão a conquistar ou conquistam algo relevante, ao mesmo tempo o futebol fará parte das discussões midiáticas esportivas a todo tempo, visto que constitui a criação da identidade e do público brasileiro, onde são catalisados os temas de interesse dos mesmos e por isso até aqui o Brasil continua sendo o país do futebol (GUEDES, 1998).

E neste momento de distanciamento social, percebemos por meio das mídias, os impactos causados com a suspensão mundial do esporte, obviamente exceção feita, segundo Abduche (2020), em países de pouca expressividade no futebol, tal como Belarus, Nicarágua e Turcomenistão.

O mesmo autor cita que, até então, somente em três situações ocorrera a paralisação das atividades ligadas ao futebol a nível mundial, nas duas guerras mundiais e na gripe espanhola, ocorrida em meados da Primeira Guerra Mundial, onde já havia uma paralisação do esporte. As discussões a serem realizadas neste período de pandemia causado pela COVID-19, que voltou a paralisar o esporte mundialmente, serão estudos pioneiros sobre como o futebol foi influenciado nesses espaços.

licere, Belo Horizonte, v.23, n.3, set/2020. 
Nessas três situações anteriores não contávamos com o espaço virtual, lócus de estudo deste artigo, e espaço de vivência de atividades do lazer contemporâneo, principalmente em tempos de distanciamento social. Esse novo momento histórico marcado pelas relações no espaço virtual é tratado por Castells (2002) como o fenômeno da "sociedade em rede", caracterizada pelo processo de relações estabelecidas por meio da informação e da sua capacidade de processamento e de geração de conhecimentos e experiências.

A sociedade em rede é analisada por Levy (1996) pela denominação “cibercultura". Segundo o autor, na cultura cibernética os seres passam a apresentar uma dinâmica diferente de interação, pautada na nova relação espaço-tempo. Kozinets (2014, p. 18) corrobora com Levy e cita que:

O termo cibercultura pode ser definido por meio de uma perspectiva futurista e tecnologicamente utópica, como um código simbólico da nova sociedade da informação, como um conjunto de práticas de estilos de vida culturais relacionados ao surgimento da tecnologia de computação em rede, ou como um termo para refletir sobre as mudanças sociais trazidas pelo acesso aos novos meios de comunicação, respectivamente.

A observação sistemática da interação por meio da internet nos possibilita perceber elementos relacionais da cultura cibernética. Entre eles se destaca a criação de comunidades, local onde usuários reúnem-se pelos mesmos interesses, problemas e/ou amizades. Este espaço compartilhado não tem uma referência estável, ou seja, não presente, sendo separado do espaço físico e, portanto, este é uma via régia da virtualização.

O termo "comunidade virtual" foi significado por Rheingold (1993, p.5), que definiu as comunidades virtuais como "agregações sociais que emergem da rede quando um número suficiente de pessoas empreende [...] discussões públicas por tempo suficiente, com suficiente sentimento humano, para formar redes de relacionamentos 
pessoais no ciberespaço", e, portanto, o Instagram se efetiva como um espaço de comunidade virtual.

O aspecto principal que deve ser observado, no que diz respeito ao espaço virtual, é o processo de comunicação, onde a vida em sociedade torna-se possível, "sendo as novas sociabilidades e relações com espaço e tempo que demarcam a vida contemporânea" (SIMÕES, 2009, p.10), principalmente quando falamos das redes móveis atuais.

Estendemos o virtual como espaço por ser possível ao sujeito acessar e vivenciar os conteúdos do lazer seja ele, físico, artístico, intelectual, manual, turístico e social sem uma referência estável e sem a obrigatoriedade de se aderir a algo, mas de propor satisfação provocada pela situação com caráter desinteressado. Sendo a vivência das atividades do lazer possíveis a partir da prática e contemplação contemporânea, alinhada a tempo e atitude.

Para se falar sobre lazer na contemporaneidade e sua vivência no espaço virtual alinhada a tempo e atitude, é necessário entendê-lo e situá-lo historicamente, por meio das discussões de autores, desde o surgimento dos estudos na área até a atualidade.

Inicialmente, o entendimento com respeito ao lazer está vinculado a sua relação com o trabalho na sociedade industrial, sendo motivo de debate em torno de mecanismos que buscavam a redução da jornada do tempo de obrigação de trabalho e o uso deste tempo como forma de lazer, o que gerava preocupação por parte dos donos do capital industrial e políticos à época (GOMES e MELO, 2003).

Este período ficou marcado por uma forte presença do ócio vicário e conspícuo, sendo o lazer deleite e forma de status apenas para pessoas com poderio financeiro (VEBLEN, 1965). O surgimento da classe ociosa é ressaltado pelo mesmo autor, como 
um marco na evolução cultural, pois a partir desse momento a riqueza tornou-se honrosa ao possuidor, principalmente a adquirida por herança e não como fruto de trabalho.

Assim, a não necessidade do trabalho e a vivência das atividades do contexto do lazer passaram a ser uma forma de demonstrar decência e poder, e o trabalho forma de sobrevivência. Ao relacionar processo de industrialização, máquina e trabalho no século XIX. Lafargue (1970, p.34) salienta que:

À medida que a máquina se aperfeiçoou e despachou o trabalho do homem com uma rapidez e uma precisão incessantemente crescente, o operário, em vez de prolongar o seu repouso proporcionalmente, redobra de ardor, como se quisesse rivalizar com a máquina. Ó ocorrência absurda e mortal!.

A reorganização no processo servil, por meio de uma nova dinâmica de distribuição de tarefas e fragmentação de espaços, marcou as mudanças não só na vivência das atividades do lazer, mas, também, em outros segmentos tais como religião, família, educação e relações interpessoais.

Harvey (1993) compara a modernização ao processo de retenção de tempo. Segundo o autor, as inovações fizeram vinte e quatro horas ser um tempo bem longo, no mercado global. Nessa forma de produtividade, o lazer passou na época a ser visto como compensatório, uma forma de procurar alívio da repressão social e um espaço onde se pode buscar excitação.

Já no século XX, as discussões acerca do lazer ganham uma nova dinâmica de sistematização na Europa e nos EUA e, a partir de 1950, passa a ser estudado como objeto nas sociedades urbano-industriais. No Brasil, segundo Marcellino (2012), os estudos relativos a temática do lazer estão associados à urbanização das grandes cidades. Não obstante, o referido autor prefere entender o lazer como:

Cultura compreendida no seu sentido mais amplo, vivenciada (praticada ou fruída) no "tempo disponível". O importante, como traço definidor, é o caráter "desinteressado" dessa vivência. Não se busca, pelo menos fundamentalmente, outra recompensa além da satisfação provocada pela situação $(1987$, p.31). 
Em decorrência dessa definição apontada pelo autor, entendemos que a análise do lazer deve ser permeada dentro de um aspecto duplo educativo, ou seja, educar para e pelo lazer, baseado em duas constatações: o lazer tomado como veículo privilegiado de educação e significação e objeto para prática e assistência. Sua compreensão deve ampliar “[...] os fios de tecido na rede humana de significados, símbolos e significações” (GOMES, 2008, p.4). A autora considera o lazer como um tempo privilegiado representativo da:

\footnotetext{
Vivência de inúmeras manifestações da cultura, tais como o jogo, a brincadeira, a festa, o passeio, a viagem, o esporte e também as formas de artes (pintura, escultura, literatura, dança, teatro, música, cinema), entre várias outras possibilidades (GOMES, 2008, p.5).
}

Não se pode esquecer de que a contemporaneidade marca uma nova dinâmica na vivência dessas manifestações culturais por meio do lazer no espaço virtual, alinhada a tempo e atitude. A retenção de tempo como forma de delongar o mesmo alterou significativamente as interações, proporcionando uma nova lógica de lazer por meio dos espaços virtuais.

A utilização do espaço virtual como lazer e a disseminação de informações e construções de laços ganham grande proporção na contemporaneidade graças aos simulacros e a dinâmica que estes transmitem. As reações corporais, na interação abstrata, podem resultar em experiências concretas, que podem produzir um lazer social que se diferenciará entre o virtual e o da presença física.

A interação no espaço virtual é uma forma de conexão entre pares de usuários e suas relações possíveis relacionadas aos laços sociais (RECUERO, 2009). Podem ser síncronas, ou seja, ao mesmo tempo, ou assíncronas em tempos distintos. Nesse sentido, são criadas conexões sociais que podem migrar a diversas plataformas digitais tornando o espaço virtual local de propagação de laços fortes e de proporções grandiosas para o desenvolvimento da prática lazer.

licere, Belo Horizonte, v.23, n.3, set/2020. 
Em relação aos mencionados laços sociais, podemos tratá-los como conexões sociais constituídas no tempo e na interação. Wellman (2001, p.7) os define como:

Laços consistem em uma ou mais relações específicas, tais como proximidade, contato frequente, fluxo de informações, conflito ou suporte emocional. A interconexão destes laços canaliza recursos para localizações específicas na estrutura dos sistemas sociais. Os padrões destas relações - a estrutura da rede social - organiza os sistemas de troca, controle, dependência, cooperação e conflito.

Com relação aos tipos, Recuero (2009, p.41) os classifica em dois, isto é, os fortes e os fracos. No entendimento da autora, os laços fortes são caracterizados "pela intimidade, pela proximidade e pela intencionalidade em criar e manter uma conexão entre duas pessoas"; já os laços fracos são dados “por relações esparsas, que não traduzem proximidade e intimidade".

Kozinets (p. 54, 2014) cita que "um vínculo fraco é aquele que é esporádico ou irregular, e tem pouca ligação emocional, já os vínculos múltiplos são mais apoiadores, duradouros, voluntários e íntimos, e também são mantidos por meio de mais fóruns ou meios diferentes". A construção de laços dá-se por meio de atividades individuais que se conectam a atividades individuais de outros usuários, praticadas no tempo disponível e podem propiciar o descanso, divertimento ou desenvolvimento pessoal e social.

Quanto à atitude, esta pode ser expressa tanto na contemplação como também na prática e estará ligada a satisfação provocada pela situação. O lazer considerado pelo viés da atitude é caracterizado pela relação entre sujeito e experiência vivida. Segundo Bondía (2002, p.21), a experiência "é o que nos passa, o que nos acontece, o que nos toca" diferente da informação cada vez mais presente na sociedade contemporânea, onde o importante seria o estar informado, opinar, resultante da falta de tempo, trabalho e a excitação por situações sem vestígios.

O mesmo autor ressalta que para que exista experiência, o sujeito deve estar aberto à receptividade do acontecer, à possibilidade de que algo o toque, e sua maneira peculiar 
de "ex-por", pois mesmo que duas pessoas enfrentem o mesmo acontecimento, não fazem a mesma experiência, pois essa é adquirida pelo que nos acontece e não pelo acontecido, assim deve ocorrer:

\footnotetext{
Um gesto de interrupção, um gesto que é quase impossível nos tempos que correm: requer parar para pensar, parar para olhar, parar para escutar, pensar mais devagar, olhar mais devagar, e escutar mais devagar; parar para sentir, sentir mais devagar, demorar-se nos detalhes, suspender a opinião, suspender o juízo, suspender a vontade, suspender o automatismo da ação, cultivar a atenção e a delicadeza, abrir os olhos e os ouvidos, falar sobre o que nos acontece, aprender a lentidão, escutar aos outros, cultivar a arte do encontro, calar muito, ter paciência e dar-se tempo e espaço (2002, p 24).
}

O acontecimento é comum a todos de um grupo onde este ocorre, mas a experiência tratada como o que nos acontece sempre será singular, entendida individual ou coletivamente. E o lazer no espaço virtual nos dá a sensação de possibilidade de criação de um "mundo" que em certo sentido podemos habitar, ou seja, "eis precisamente a razão pela qual devemos acompanhar os seus desenvolvimentos, conter seus usos eticamente questionáveis e pensar nos seus fundamentos” (QUÉAU, 1993, p.99).

Dentre os principais motivos evidenciados pela busca do espaço virtual para o lazer, segundo Schwartz et al. (1998), estão a diversão e a interação social, e os conteúdos virais aqui estudados, podem ser citados como exemplos, pois se tornaram moda e marca registrada aos frequentadores deste espaço e somente dele.

Rossini (2014, p.21) caracteriza conteúdos virais como “todo conteúdo propagado na internet, numa progressão aritmética ou geométrica, desprovido de "utilidade concreta", servindo como forma de humor ou lazer" e os memes são configurados como conteúdos virais propagados por pessoas.

\section{Metodologia}

Trata-se de uma pesquisa de campo on-line, que possuiu como técnica de coleta de dados o diário de bordo onde foram anotadas as propagações de memes, seus temas e tipos, em três páginas futebolísticas do Instagram. Esta técnica nos permitiu coletar dados

licere, Belo Horizonte, v.23, n.3, set/2020. 
de forma síncrona e assíncrona sobre as postagens, sendo utilizado o sistema de print (captura de tela) para armazenamento dos memes.

Com efeito, subsidia a análise das características e classificações dos memes, pois foi possível a partir das anotações contemplar as impressões que ao longo da pesquisa poderiam se perder. Escrever notas de campo e arquivar fatos no instante em que se usufrui das experiências sociais on-line interativas é importante, porque esses processos de aprendizagem, socialização e aculturação são sutis e nossas recordações deles rapidamente se diluem.

Foi utilizado como tempo de coleta os trinta dias anteriores e posteriores à nota de 16 de março de 2020 expedida pela Confederação Brasileira de Futebol (CBF), que suspendeu os campeonatos desse esporte por tempo indeterminado, como medida de combate à COVID-19 no Brasil.

A escolha das páginas de Instagram se deu em razão dos laços de pertencimento dos pesquisadores em suas redes de sociabilidade neste espaço virtual. Segundo Piza (2012), o Instagram é uma rede social em evolução no Brasil. Criada no ano de 2010, pelo norte-americano Kevin Systrom e pelo brasileiro Mike Krieger, ambos os engenheiros de software. É um espaço onde o usuário pode postar fotos, memes, vídeos de curta duração e sua interação é realizada por meio de curtidas ou comentários e também pelo acompanhamento das postagens do amigo virtual, seguindo-o. Aliás, nesse espaço, quanto maior o número de seguidores, maior será a visibilidade do perfil.

Utilizou-se como recorte para análise três páginas do total de onze, que tinham realizado postagens de memes trinta dias antes da nota supracitada, sendo escolhida uma página com maior número de publicações, uma com menor número de publicações e uma intermediária, na tentativa de entender o alcance da influência da COVID-19 trinta dias 
após a nota da CBF quanto à possibilidade de vivência das atividades do lazer dos CDC's em distintas páginas futebolísticas de Instagram.

É necessário considerar que as três páginas estudadas não são ambientes de publicidade obrigatória dos memes e nem monetização, pois era evidente, em ambas, a falta de patrocinadores ou propagandas que poderiam evidenciar estes espaços virtuais como um local de trabalho e obrigatoriedade, o que iria contra o conceito de lazer utilizado neste artigo.

A primeira página, com maior número de publicações e identificada pela letra $\mathbf{A}$, até o fechamento do artigo, possuía 3.251 publicações e 106 mil seguidores. Na pesquisa, sua contribuição foi com somatório de 259 publicações de memes anteriores à nota da CBF, representando $63 \%$ do total, e somatório de 299 publicações posteriores, ou seja, 39,5\% do total (ver Tabela 1). Seu lema é "aqui misturamos ironia, um pouco de conhecimento, e claro, muita Zueira!".

A segunda página, tratada como intermediária, por se encontrar no meio da quantidade de publicações referenciadas para pesquisa e identificada pela letra $\mathbf{B}$, realizou um total de 5.804 publicações e possui 282 mil seguidores. Na pesquisa sua contribuição foi com somatório de 130 publicações anteriores à nota referenciada, representando $31,6 \%$ do total, e somatório de 171 posteriores, ou seja, 22,6\% do total (ver tabela 1). Seu lema é "aqui nós torcemos para seu time... perder!".

Por fim, a terceira página, com menor número de postagens anterior à nota da $\mathrm{CBF}$ e identificada pela letra $\mathbf{C}$, publicou 2.363 vezes e possui 47,6 mil seguidores. Contribui com a pesquisa com somatório de 22 publicações anteriores à nota em referência, representando 5,4\% do total e somatório de 287 posteriores, ou seja, 37,9\% do total (ver tabela 1). Seu lema é "memes de procedência duvidosa a respeito do esporte mais popular e querido do mundo". 
Os tipos de memes propagados nas três páginas foram analisados com base em Doncel (2016), que os classifica em visual, textual, verbo visual e adicionamos a essa discussão o verbo audiovisual. Os dados analisados tiveram como referência a técnica de codificação analítica tal qual aduzida por Kozinets (2014), onde se busca afixar categorias para dados retirados de fontes on-line, sendo atribuídos códigos, classificações, nomes ou rótulos a determinadas unidades.

Esses códigos rotulam os dados como pertencentes ou como um exemplo de algum fenômeno mais geral; categorias de codificação geralmente emergem indutivamente por meio de uma leitura atenta dos dados, em vez de serem impostas por categorias prescritas (p.114).

Os temas dos memes nas três páginas tiveram como critério de construção a análise interpretativa das significações que as postagens proporcionaram aos autores, sendo possível identificar as seguintes categorias a) Futebol e reality show; b) Futebol e clubes; c) Futebol e COVID - 19; d) Futebol e vida pessoal de jogadores; e) Futebol e racismo; f) Futebol e violência; g) Futebol e prostituição; h) futebol, música e dança; i) Futebol e apostas e j) Futebol e beleza.

É importante salientar que as três páginas analisadas se seguem no espaço virtual, ou seja, estão conectadas entre si, e isso serviu de base para a análise das características e classificações dos memes à luz das contribuições de Dawkins (2001) e Recuero (2009), por meio de características fecundidade, fidelidade, longevidade e alcance e também por classificação em memes replicadores, metamórficos, miméticos, persistentes, voláteis, epidêmicos fecundos, globais e locais.

\section{Resultados e Discussão}

Com o intuito de proporcionar uma visão geral sobre as relações estabelecidas entre a teoria e a interpretação dos dados coletados, a lógica de apresentação partirá da relação entre propagação e tipos para, posteriormente, realizarmos o diálogo com os temas. 
Ao analisarmos as propagações e tipos de memes, percebemos que houve aumento de $84,2 \%$, quanto à quantidade de publicações nas três páginas, uma vez comparado o período anterior e posterior de trinta dias da publicação da nota da CBF. Quando avaliamos os memes por seus tipos, notamos que houve crescimento de publicações de $46,7 \%$ dos memes verbo visual, $600 \%$ visual, $268,2 \%$ textual e $442,9 \%$ verbo audiovisual, (ver Tabela 1).

Outro dado que chamou atenção foi que as páginas tendem a publicar em maior quantidade os memes verbo visual, que representaram $88,6 \%$ do total nos trinta dias inicias de coleta, e, apesar de uma leve queda, permaneceram na liderança com 70,5\% nos trinta dias posteriores à nota da $\mathrm{CBF}$ (ver Tabela 1$)$.

Houve uma inversão quanto aos memes textual e verbo audiovisual: enquanto os memes textual apresentaram-se em maior quantidade nos trinta dias anteriores à paralisação, nos trinta dias posteriores à paralisação os memes verbo audiovisual se mostraram em maior presença. Esses dados nos levam ao entendimento segundo o qual o tempo disponível é o principal fator na produção dos memes, pois os memes verbo audiovisual requerem dispender um maior tempo, dada sua complexidade de produção (ver Tabela 1).

Já os memes visual são os menos publicados, representando 1,0\% e 3,7\% (ver tabela 1) no montante geral de publicações das páginas futebolísticas do Instagram, sendo, portanto, memes com menor poder de viralização nessa rede de socialização virtual.

Quanto à influência da COVID-19, identificou-se que todas as páginas analisadas tiveram um aumento no número de publicações. A página $\mathbf{C}$ foi a que apresentou o maior crescimento, 1.204,5\%; a página $\mathbf{B}$ cresceu 31,5\% em publicações, e a página $\mathbf{A}$ em 15,4\%. Mesmo com menor crescimento no número de publicações, a página $\mathbf{A}$ manteve 
sua liderança quanto à quantidade, seguida pela $\mathbf{C}$, que se encontrava na última posição antes do período de distanciamento social, referenciado a partir da nota da CBF, superando a $\mathbf{B}$ (ver Tabela 1).

O distanciamento social provocado pela pandemia de COVID-19 influenciou na vivência das atividades do lazer dos CDC's, o que pode ser constatado com a maior produção e propagação de memes nas suas respectivas páginas futebolísticas de Instagram. Possivelmente, isso se deve à inviabilidade de se realizar este lazer em espaços presenciais e a reorganização de tempo alinhada à atitude (prática e contemplação).

Tabela 1: Propagação e tipos de memes em três páginas futebolísticas de Instagram.

\begin{tabular}{|c|c|c|c|c|c|c|c|c|}
\hline & \multicolumn{2}{|c|}{$\begin{array}{l}\text { Memes anteriores } \\
\text { à nota da CBF }\end{array}$} & \multicolumn{2}{|c|}{$\begin{array}{c}\text { Memes após a nota } \\
\text { da CBF }\end{array}$} & \multirow[t]{2}{*}{$\begin{array}{c}\text { Total geral } \\
\text { de } \\
\text { publicações }\end{array}$} & \multicolumn{2}{|c|}{ Aumento } \\
\hline & & Qtd & $\%$ & Qtd & $\%$ & & Qtd & $\%$ \\
\hline \multirow{4}{*}{$\begin{array}{c}\text { Páginas } \\
\text { pesquisadas }\end{array}$} & A & 259 & $63,0 \%$ & 299 & $39,5 \%$ & 558 & 40 & $15,4 \%$ \\
\hline & B & 130 & $31,6 \%$ & 171 & $22,6 \%$ & 301 & 41 & $31,5 \%$ \\
\hline & $\mathrm{C}$ & 22 & $5,4 \%$ & 287 & $37,9 \%$ & 309 & 265 & $1204,5 \%$ \\
\hline & Total & 411 & $100,0 \%$ & 757 & $100,0 \%$ & 1168 & 346 & $84,2 \%$ \\
\hline \multirow{5}{*}{$\begin{array}{c}\text { Tipos de } \\
\text { memes } \\
\text { encontrados } \\
\text { nas páginas }\end{array}$} & $\begin{array}{l}\text { Memes } \\
\text { Verbo } \\
\text { visual }\end{array}$ & 364 & $88,6 \%$ & 534 & $70,5 \%$ & 898 & 170 & $46,7 \%$ \\
\hline & $\begin{array}{c}\text { Memes } \\
\text { Visual }\end{array}$ & 4 & $1,0 \%$ & 28 & $3,7 \%$ & 32 & 24 & $600,0 \%$ \\
\hline & $\begin{array}{l}\text { Memes } \\
\text { Textual }\end{array}$ & 22 & $5,4 \%$ & 81 & $10,7 \%$ & 103 & 59 & $268,2 \%$ \\
\hline & $\begin{array}{c}\text { Memes } \\
\text { Verbo } \\
\text { audiovisual }\end{array}$ & 21 & $5,1 \%$ & 114 & $15,1 \%$ & 135 & 93 & $442,9 \%$ \\
\hline & Total & 411 & $100,0 \%$ & 757 & $100,0 \%$ & 1168 & 346 & $84,2 \%$ \\
\hline
\end{tabular}

Fonte: Elaborada pelos autores (2020).

A análise dos temas foi organizada em categorias a partir da propagação dos memes, originando o total de dez, como pode ser verificado na Tabela 2. As categorias se repetiram nos dois momentos de coleta, exceto a de futebol e apostas presentes somente no primeiro momento, e a categoria futebol, música e dança no segundo momento.

Os dados apresentados são resultantes da coleta nas três páginas conjuntas e visam entender quais categorias de memes estiveram presentes, em qual momento e quais se 
sobressaíram, além de comparação individual de queda ou crescimento possuindo como referência a nota da CBF.

Tabela 2: Categorias e propagação de memes futebolísticos.

\begin{tabular}{|c|c|c|c|c|c|c|c|}
\hline \multirow[t]{2}{*}{ Categoria } & \multicolumn{2}{|c|}{$\begin{array}{c}\text { Total anterior à } \\
\text { nota da CBF }\end{array}$} & \multicolumn{2}{|c|}{$\begin{array}{l}\text { Total após a nota } \\
\text { da CBF }\end{array}$} & \multirow{2}{*}{$\begin{array}{c}\begin{array}{c}\text { Total geral } \\
\text { de } \\
\text { publicações }\end{array} \\
\text { Qtd }\end{array}$} & \multicolumn{2}{|c|}{ Variação } \\
\hline & Qtd & $\%$ & Qtd & $\%$ & & Qtd & $\%$ \\
\hline $\begin{array}{c}\text { Futebol e } \\
\text { apostas }\end{array}$ & 4 & $1,0 \%$ & 0 & $0,0 \%$ & 4 & -4 & $-100 \%$ \\
\hline $\begin{array}{l}\text { Futebol e } \\
\text { violência }\end{array}$ & 12 & $2,9 \%$ & 5 & $0,7 \%$ & 17 & -7 & $-58 \%$ \\
\hline $\begin{array}{c}\text { Futebol e } \\
\text { racismo }\end{array}$ & 3 & $0,7 \%$ & 2 & $0,3 \%$ & 5 & -1 & $-33 \%$ \\
\hline $\begin{array}{c}\text { Futebol e } \\
\text { beleza }\end{array}$ & 4 & $1,0 \%$ & 6 & $0,8 \%$ & 10 & 2 & $50 \%$ \\
\hline $\begin{array}{l}\text { Futebol e } \\
\text { prostituição }\end{array}$ & 2 & $0,5 \%$ & 20 & $2,6 \%$ & 22 & 18 & $900 \%$ \\
\hline $\begin{array}{l}\text { Futebol e } \\
\text { COVID-19 }\end{array}$ & 4 & $1,0 \%$ & 27 & $3,6 \%$ & 31 & 23 & $575 \%$ \\
\hline $\begin{array}{l}\text { Futebol e } \\
\text { reality show }\end{array}$ & 11 & $2,7 \%$ & 332 & $43,9 \%$ & 343 & 321 & $2.918 \%$ \\
\hline $\begin{array}{l}\text { Futebol e } \\
\text { clubes }\end{array}$ & 362 & $88,1 \%$ & 306 & $40,4 \%$ & 668 & -56 & $-15 \%$ \\
\hline $\begin{array}{c}\text { Futebol e } \\
\text { vida pessoal } \\
\text { de jogadores }\end{array}$ & 9 & $2,2 \%$ & 40 & $5,3 \%$ & 49 & 31 & $344 \%$ \\
\hline $\begin{array}{c}\text { Futebol, } \\
\text { música e } \\
\text { dança }\end{array}$ & 0 & $0,0 \%$ & 19 & $2,5 \%$ & 19 & 19 & $---\cdot$ \\
\hline Total geral & 411 & $100,0 \%$ & 757 & $100,0 \%$ & 1168 & 346 & $84,2 \%$ \\
\hline
\end{tabular}

Fonte: Elaborada pelos autores (2020).

Entendemos que a maior influência da COVID-19 na propagação de memes se fez presente nos temas categorizados como futebol e clubes e futebol e reality show. A categoria futebol e clubes representava $88,1 \%$ do memes postados nas páginas anteriores à nota da CBF de suspensão do futebol, após, representava 40,4\% do total, ou seja, uma variação de $-15 \%$ no total de memes propagados (ver Tabela 2).

Já a categoria de futebol e reality show representava $2,7 \%$ do total de memes coletados anteriormente à nota supracitada, e, com a suspensão do futebol, passou para 43,9\% do total. Analisada, separadamente, cresceu $2.918 \%$ no período de coleta de dados

licere, Belo Horizonte, v.23, n.3, set/2020. 
após a nota da $\mathrm{CBF}$, tornando-se o assunto mais propagado por meio de memes nas páginas futebolísticas (ver Tabela 2).

Como já discutido no referencial teórico, o futebol faz parte da construção da identidade cultural do brasileiro (LAGES e SILVA, 2012), com sua suspensão, a não transmissão ao vivo e a diminuição de assuntos que poderiam produzir novos memes, os CDC's buscaram o alinhamento desse fenômeno a outra manifestação cultural que estivesse em evidência, e isso pode ser justificado pelo processo de identidades e identificações citado por Murad (2012) no artigo.

Na soma total dos memes, a terceira categoria de maior propagação foi futebol e vida pessoal de jogadores, seguida em quarto por futebol e COVID-19, quinto futebol e prostituição, sexto futebol, música e dança, sétimo futebol e violência, oitavo futebol e beleza, nono futebol e racismo, e na última posição futebol e apostas. (ver Tabela 2).

A seguir são apresentados exemplos de memes que serviram de modelo para categorização (ver Figuras de 5 a 14). É importante salientar que foram preservadas as marcas d'água que identificam as páginas que realizaram as propagações no intuito de resguardo das mesmas. Os memes que poderiam causar danos reais aos sujeitos tiveram

\section{Figura 5: Meme característica futebol e beleza.}

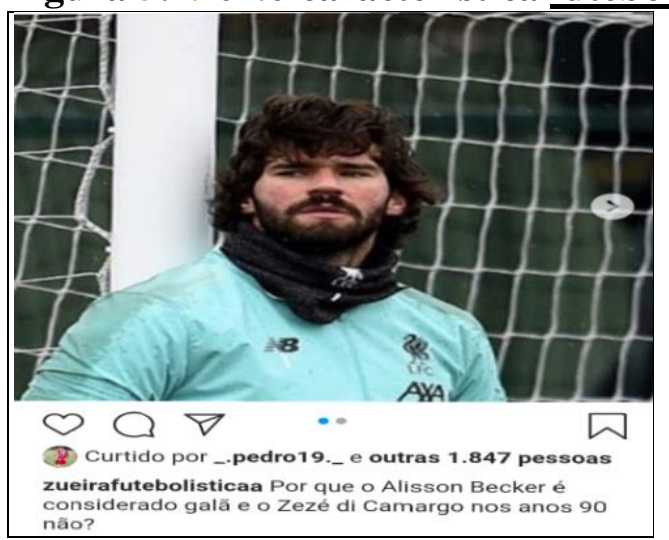

Disponível em: http://www.instagram.com/p/B87SmK5Bsdi/?utm_source=ig_web_button_share_sheet Acesso em: 23 fev. 2020 
Figura 6: Meme característica futebol e prostituicão.

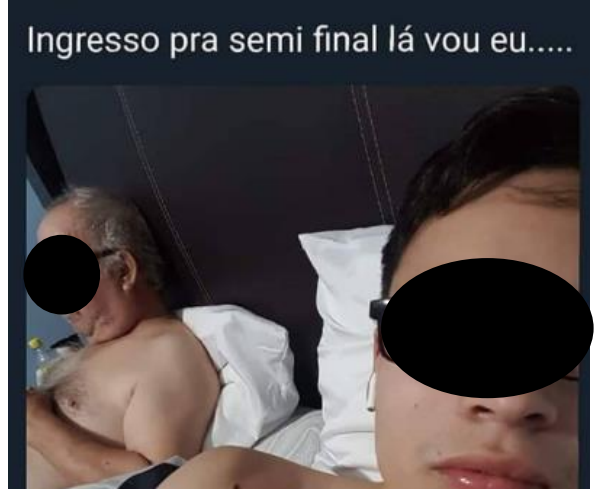

Disponível em: https://www.instagram.com/p/B_Bb-FVBv-F/?utm_source=ig_web_button_share_sheet Acesso em: 15 abr. 2020

\section{Figura 7: Meme característica futebol e vida pessoal de jogadores}

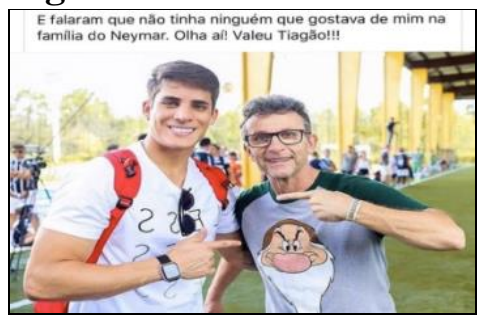

Disponível em: www.instagram.com/p/B-4_PKCh81_/?utm_source=ig_web_button_share_sheet Acesso em: 12 abr. 2020

\section{Figura 8: Meme característica futebol e COVID- 19}

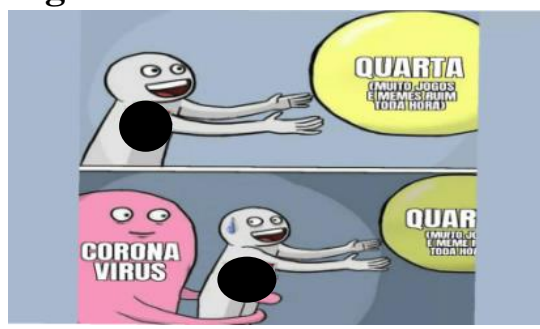

Disponível em: www.instagram.com/p/B-NJa-5BHgQ/?utm_source=ig_web_button_share_sheet Acesso em: 26 mar 2020

\section{Figura 9: Meme característica futebol e reality show.}

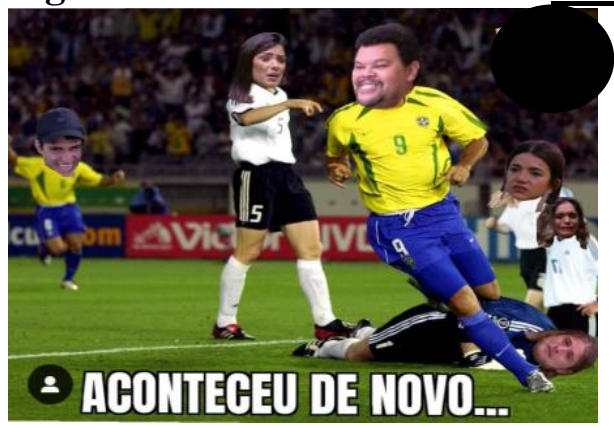

Disponível em: www.instagram.com/p/B-503rHBtWR/?utm_source=ig_web_button_share_sheet Acessado em: 12 abr. 2020 
Figura 10: Meme característica futebol e violência.

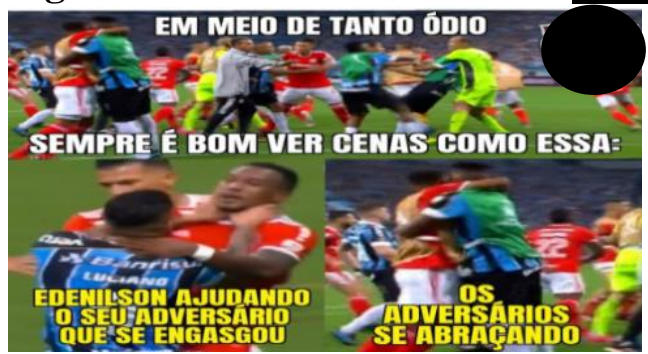

Disponível em: www.instagram.com/p/B9qEzgLhO-b/?utm_source=ig_web_button_share_sheet Acessado em: 12 mar. 2020

\section{Figura 11: Meme característica futebol e racismo.}

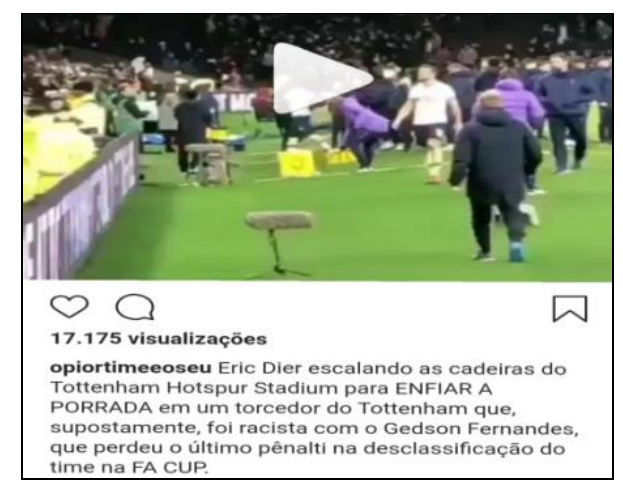

Disponível em: www.instagram.com/opiortimeeoseu/. Acesso em: 04 mar. 2020

\section{Figura 12: Meme característica futebol, música e danca.}

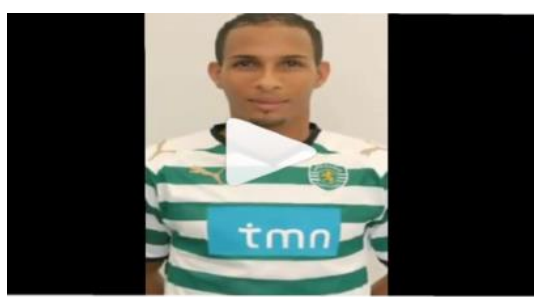

Disponível em: www.instagram.com/p/B9JyyekhwV6/?utm_source=ig_web_button_share_sheet Acesso em: 29 fev. 2020

\section{Figura 13: Meme característica futebol e clubes.}

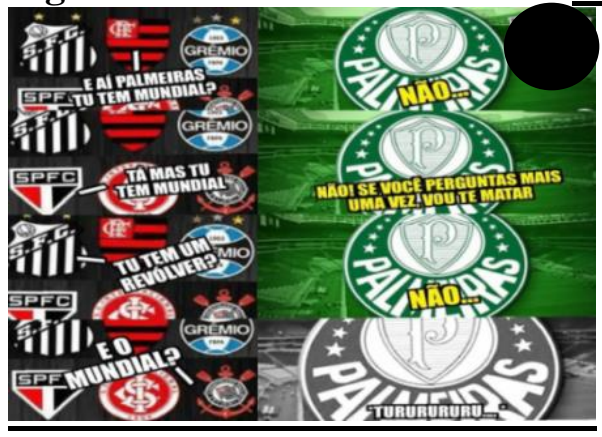

Disponível em: www.instagram.com/p/B-ClX8wBu6k/?utm_source=ig_web_button_share_sheet Acesso em: 22 mar. 2020

licere, Belo Horizonte, v.23, n.3, set/2020. 


\section{Figura 14: Meme característica futebol e apostas.}

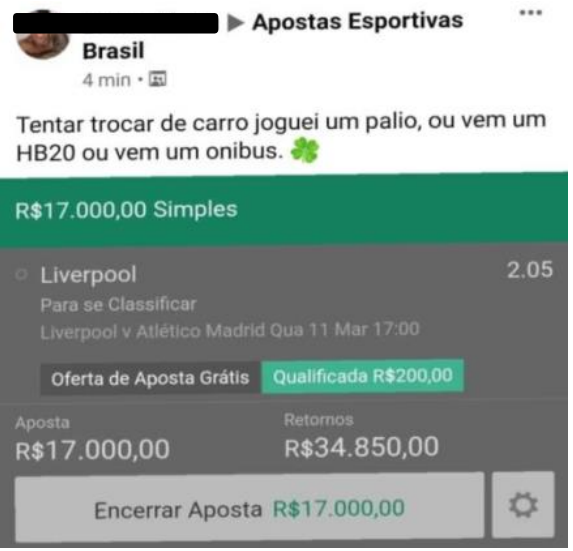

Disponível em: www.instagram.com/opiortimeeoseu/. Acesso em: 11 mar. 2020

Realizamos, também, análise a partir de Dawkins (2001) e Recuero (2009) tendo em vista as características e classificações dos memes, sendo arquivadas no diário de bordo todas as impressões e contemplações das experiências sociais proporcionadas aos autores. É importante ressaltar, novamente, que as três páginas pesquisadas se seguem, ou seja, estão conectadas no espaço virtual Instagram.

Nessa investigação não comparamos o antes e o depois da nota da $\mathrm{CBF}$, pois verificamos que as postagens seguiam a mesma lógica dentro das categorias e que seria mais interessante a pesquisa discriminar as classificações e características dos memes.

Não necessariamente cada categoria irá apresentar todas as características e classificações. As categorias futebol e racismo, futebol e apostas, e futebol e beleza, apresentaram a mesma lógica de propagação de seus memes, sendo classificados como voláteis na característica de longevidade.

Outras três categorias se apresentaram voláteis nas características de longevidade, mas apresentaram outros quesitos de análise, a saber: a) futebol e prostituição, na qual foi perceptível também a característica alcance, sendo classificados como memes locais; b) futebol, música e dança, desenvolveu a característica de fidelidade por meio de memes replicadores; c) futebol e vida pessoal de jogadores apresentaram na característica fidelidade serem replicadores e quanto ao alcance memes globais. 
A categoria futebol e violência evidenciou a característica fidelidade por meio de memes metamórficos. Por fim, as três categorias restantes se apresentaram da seguinte forma: a) futebol e COVID-19, característica fecundidade, memes classificados como epidêmicos, característica alcance, memes classificados como globais; b) futebol e reality show, característica fidelidade, memes replicadores, característica fecundidade, memes epidêmicos, característica longevidade, memes persistentes e característica alcance, memes globais; c) Futebol e clubes, na característica fidelidade encontramos memes replicadores e metamórficos; característica fecundidade, memes epidêmicos e característica alcance, memes globais.

\section{Conclusão}

Os dados aqui apresentados nos dão elementos para concluir que os memes são produções que sempre possuem um alvo, e que seu sucesso está ligado ao ocorrido cotidianamente de algo engraçado e inusitado, que possam dar alcance e retorno, fazendo valer as oportunidades e a estratégias em postá-los.

No período pandêmico, notou-se que os CDC's se apropriaram de outros temas das manifestações da cultura brasileira para suas postagens e que o distanciamento social, medida de enfrentamento à COVID-19, influenciou na vivência das atividades do lazer quanto ao aumento da quantidade de propagações de memes. Isso nos remete a pensar que o Instagram se tornou um espaço virtual que produz significações ao futebol seja por meio da produção, veiculação, como também para o consumo das postagens.

Quanto aos impactos da pandemia na propagação de memes por seus tipos, houve aumento de ocorrência em todos, com ênfase para os memes verbo visual que se mantiveram como os de maior propagação e também os memes verbo audiovisual que passaram a ser o segundo tipo de memes com maior propagação. Os CDC's vinculam a 
produção dos memes verbo audiovisual a vida pessoal e futebolística do jogador com a ocorrência de situações corriqueiras do dia a dia.

Esse trabalho é uma contribuição para o entendimento sobre a vivência do futebol em tempos de pandemia, mostrando que o espaço virtual tornou-se local que pode potencializar a vivência de atividades do lazer vinculada a esse esporte. É importante salientar que esta vivência estará ligada ao tempo disponível, atitude, prática e contemplação.

O limite dessa pesquisa diz respeito a investigação da propagação de apenas 30 dias antes e depois da pandemia, em que foram analisados seus temas e tipos de memes em páginas futebolísticas de Instagram. Sugere-se estudos futuros quanto a permanência dos impactos causados pela enfermidade epidêmica em curso e se esta antecipou uma tendência mundial de virtualização das vivências de atividades do lazer ou ainda se a mesma exigirá novas vivências de sociabilidade no formato presencial tradicional.

\section{REFERÊNCIAS}

ABDUCHE, R. Coronavírus: veja o mapa da paralisação no futebol mundial. Rio de janeiro, 2020. Disponível em: http://interativos.globoesporte.globo.com/futebol/futebolinternacional/materia/mapa-do-coronavirus-futebol-internacional. Acesso em: 14 maio 2020 .

BONDÍA, J. L. Notas sobre a experiência e o saber da experiência. Revista Brasileira de Educação, n.19, v.1, 2002.

BRASIL. Ministério da Saúde. Sobre a doença. Disponível em: https://coronavirus.saude.gov.br/. Acesso em: 24 abr. 2020.

CASTELLS, M. A sociedade em rede. Lisboa: Fundação Calouste Gulbenkian, 2002.

CBF. Confederação Brasileira de Futebol. CBF suspende competições de âmbito nacional por tempo indeterminado. Disponível em http://www.cbf.com.br/acbf/informes/index/cbf-suspende-competicoes-de-ambito-nacional-por-tempoindeterminado. Acesso em: 16 mar. 2020.

DAWKINS, Richard. O gene egoísta. Belo Horizonte: Editora Itatiaia, 2001. 
DONCEL, E. B. Circulación de memes en WhatsApp: ambivalencias del humor desde la perspectiva de género. EMPIRIA. Revista de Metodología de Ciencias Sociales. n. 35, v.3, p. 21-45, 2016.

FONTANELLA, Fernando. O que é um meme na Internet? Proposta para uma problemática da memesfera. In: SIMPÓSIO NACIONAL DA ABCiber, n.3, p. 1-16, 2009, São Paulo.

GOMES, C. L. Lazer Urbano, Contemporaneidade e educação das sensibilidades. Rio de Janeiro - (UNIRIO) Revista Itinerarium, v.1, n.1, p. 1-18, 2008.

.; MELO, V. A. Lazer no Brasil: trajetória de estudos, possibilidades de pesquisa. Porto Alegre: Movimento, v.9, n.1, p.23-44, 2003.

GUEDES, S. L. O Brasil no campo de futebol: estudos antropológicos sobre os significados do futebol brasileiro. Niterói: EDUFF, 1998.

HARVEY, D. A condição pós-moderna: uma pesquisa sobre as origens da mudança cultural. Oxford: Cowley Road, 1989. São Paulo: Loyola, 1993.

KOZINETS, R. V. Netnografia: realizando pesquisa etnográfica online. Porto Alegre: Penso, 2014.

LAFARGUE, P. O direito a preguiça. Lisboa: Estampa, 1970.

LAGES, C. E. D. M; SILVA, S. R. Futebol e lazer: diálogos e aproximações. Licere (Centro de Estudos de Lazer e Recreação. Online), v. 15, n.1, p. 1-13, 2012.

LÉVY, P. O que é o virtual? Rio de Janeiro: Editora 34, 1996.

MACEDO, Y. M. ORNELLAS, J. L. BOMFIM, H. F. Covid-19 no Brasil: o que se espera para a população subalternizada? Revista Encantar - Educação, Cultura e Sociedade. Bom Jesus da Lapa, v.2, p.01-10, jan/dez. 2020.

MARCELLINO, N. C. Lazer e educação. Campinas: Papirus, 1987.

Estudos do lazer: uma introdução. Campinas: Autores Associados, 2012.

MURAD, M. A violência no futebol. São Paulo: Saraiva, 2012.

PIZA, M. V. O fenômeno Instagram: considerações sobre a nova perspectiva tecnológica. Brasília: Universidade de Brasília, 2012.

QUÉAU P. O tempo do virtual. In: PARENTE, A. (org.). Imagem Máquina: A era das tecnologias do virtual. Rio de Janeiro: Coleção Trans, 1993.

RECUERO, R. Redes Sociais na Internet. Porto Alegre: Sulina, 2009.

RHEINGOLD, H. La Comunidad Virtual: Uma Sociedad sin Fronteras. Barcelona: Gedisa Editorial, 1993.

ROSSINI, V. S. Os manjadores entenderão: os conteúdos virais e a sociabilidade no ciberespaço. Pontourbe, São Paulo, v. 14, n. 1, p. 1-27, 2014.

licere, Belo Horizonte, v.23, n.3, set/2020. 
SCHWARTZ, G. M. et al. A internet como espaço de lazer. In Simpósio Internacional de Ciências do Esporte, n.21, 1998, São Paulo. Anais... São Paulo, 1998.

SIMÕES, I. A. G. A sociedade em Rede e a Cibercultura: dialogando com o pensamento de Manuel Castells e de Pierre Levy na era das novas tecnologias de comunicação. Temática, v. 5, n.5, 2009.

VEBLEN, T. A teoria da classe ociosa. São Paulo: Pioneira, 1965.

WELlMAN, B. Physical Place and Cyberplace: The Rise of Personalized Networking. Fevereiro de 2001. International Journal of Urban and Regional Research, v.2, n.25, 2001.

\section{Endereço dos Autores:}

Wesley Marques da Silva

Universidade do Estado de Minas Gerais (UEMG)

Rua Vereador Geraldo Moisés da Silva s/n - Universitário

Itutitaba - MG - 38.302-192

Endereço eletrônico: wesley.silva@uemg.br

Ari Lazzarotti Filho

Faculdade de Educação Física

Universidade Federal de Goiás (UFG)

Av. Esperança, s/n - Chácaras de Recreio Samambaia

Goiânia - GO - 74.690-900

Endereço eletrônico: lazzarotti@ufg.br 